Глава 2. Интродукция и сортоизучение

\title{
CHANGES IN THE QUANTITATIVE FEATURES OF GARDEN ROSE LEAVES FROM VARIOUS FUNCTIONAL GROUPS
}

\author{
Klemeshova K. V., Budarin A. A. \\ Federal Research Centre \\ the Subtropical Scientific Centre of the Russian Academy of Sciences, \\ Sochi, Russia,e-mail: klemeshova_kv@mail.ru
}

The paper presents a statistical analysis of leaf morphological features for 20 garden rose cultivars from various functional groups (bushy, large-flowered, multi-flowered, groundcover and climbing). In order to develop a more advanced method for a comprehensive assessment of ornamental nature in garden and park roses growing in the humid subtropics of Russia it is necessary to carefully study the complex of quantitative features of assimilation apparatus and identify the most important ones that are approved for cultivars. Thus, in order to develop a classification it is possible to use the roundness index (apical and lateral leaves, variation coefficient of $18.2 \%$ and $17.0 \%$, respectively) and the thickness of a leaf blade ( $\mathrm{V}=21.4 \%)$ from among the quantitative features.

Key words: Rosa $\times$ hybrida hort., garden group, leaf, morphological features, coefficient of variation.

\section{ХАРАКТЕРИСТИКА СОРТОВ ФУНДУКА НОВОГО ПОКОЛЕНИЯ В КОЛЛЕКЦИИ ФИЦ СНЦ РАН}

Махно В. Г., Тутберидзе Ц. В., Беседина Т. Д.

\author{
Федеральное государственное бюджетное учреждение науки \\ «Федеральный исследовательский центр «Субтропический научный иентр \\ Российской академии наук», \\ 2. Сочu, Pоссия, e-mail: supk@vniisubtrop.ru
}

Важнейшим элементом технологии выращивания фундука (Corylus pontica C. Koch) является сортимент. Сорт с комплексом хозяйственно-ценных признаков является основой производства качественных и конкурентоспособных плодов (орех) этой весьма ценной культуры. Основной базой для селекции фундука является генофонд, который в ФИЦ СНЦ РАН формировался за счёт интродукции сортов и форм из различных природных регионов СНГ и Европы, а также путём пополнения его формами и сортами собственной селекции. В результате селекционной работы созданы высокопродуктивные сорта фундука, которые в 2019 г. были зарегистрированы в Государственном реестре охраняемых селекционных достижений РФ, из них раннего срока созревания: ‘Анастасия', 'Галина' и позднего - 'Виктория'. Они отличаются 
стабильностью плодоношения, высокими вкусовыми и полезными качествами, относительно устойчивы к абиотическим и биотическим факторам.

Ключевые слова: фундук, коллекция, сорта, куст, побеги, листья, женские и мужские цветы, орехи(плоды), достоинства и недостатки сорта.

Краснодарский край является уникальным регионом Российской Федерации, почвенно-климатические и экологические условия которого благоприятны для выращивания культуры фундука (Corylus pontica C. Косh.). Основные насаждения которой сконцентрированы на Черноморском побережье, что далеко не отвечает потенциальным возможностям этой культуры. Сдерживающими факторами значительного увеличения объёмов производства, повышения урожайности фундука являются: устаревший сортимент, возрастной состав насаждений, требующий реконструкции, несовременные подходы к технологии производства посадочного материала, крайне медленный переход на более прогрессивные конструкции насаждений и формировки $[1,2]$.

В современных экономических условиях из всего многообразия задач повышения эффективности производства ореха фундука, необходимо сконцентрировать внимание на выполнение тех, решение которых гарантирует стабильно-высокую урожайность и качество продукции, не уступающее зарубежным производителям [3-6].

Учитывая огромный спрос населения нашей страны на продукцию фундука, а кондитерской промышленности на сырье, необходимость расширения сортимента для промышленной базы этой культуры весьма актуальна $[7,8]$.

Цель исследований: выявить из имеющейся коллекции перспективные сорта, наиболее продуктивные, с хорошим качеством плодов и устойчивые к стресс-факторам, для закладки промышленных насаждений и дальнейшей селекционной работы.

Объекты и методы исследований. Объекты исследований - сорта и формы Corylus pontica C. Кoch. Оценка новых форм и сортов фундука проводились по общепринятым методикам $[9,10]$.

Сорта и формы оценивались по основным и хозяйственно-ценным признакам (урожайность, качество орехов, адаптивная способность).

Результаты исследований. В настоящее время перед ореховодами Российской Федерации стоит задача - обеспечить население нашей страны орехами ценной культуры фундука за счёт увеличения объёмов её производства и внедрения новых высокопродуктивных сортов. При возделывании фундука в технологическом процессе ведущая роль принадлежит сорту. Правильно подобранный сорт, применительно к местным 
Глава 2. Интродукция и сортоизучение

условиям произрастания, позволяет получать стабильную урожайность с высоким качеством готовой продукции.

Фундук - это не только ценная орехоплодная культура, она ещё и очень декоративная. Кроме сортов с зелёными листьями, есть ещё и с красными, с рассеченными листьями, которые могут стать украшением любого сада $[11,12]$.

В коллекции ФИЦ СНЦ РАН (ранее ВНИИЦиСК) изучаются сорта фундука зарубежной и отечественной селекции [13]. В результате исследований были выделены перспективные сорта, которые в 2019 г. зарегистрированы в Государственном реестре охраняемых селекционных достижений РФ, из них два сорта фундука раннего срока созревания: 'Анастасия', 'Галина' и один позднего - 'Виктория'.

Описание сортов нового поколения, представлены ниже:

Сорт 'АНАСТАСИЯ'

Сорт раннего срока созревания, селекции ФИЦ СНЦ РАН (ранее ВНИИЦиСК), выделен в 1992 г. среди форм от свободного опыления на Черноморском побережье Краснодарского края (рис. 1).

Авторы сорта: В. Г. Махно, А. В. Рындин, Л. В. Черепенина

Куст средней силы роста, с овальной, средней густоты кроной, достигающей 3,0 м высоты и 3,0-3,5 м в диаметре; расположение скелетных ветвей компактное.

Орехи: крупные (длина 26 мм, ширина 24 мм); форма округлая; вершина слегка заостренная; основание бугристое; собраны в соплодия по 4-8 шт. (в среднем 4-6); обертка (плюска) зелёного цвета, состоит из двух лопастей, немного длиннее ореха, у вершины открытая, рассеченная на несколько удлинённых долей со слабым наплывом у основания, при созревании ореха легко отделяется; скорлупа средняя (толщиной 1,0 мм), слаборебристая, светло-коричневая; ядро массой 1,3-1,5 г, плотное, хорошо заполняет скорлупу и составляет 50 \% от общей массы ореха, содержит: жира - 70 \%, белка - 17 \%, витамины В1, В2, В6, Е; в контролируемых условиях плоды хранятся до 3 лет, не теряя своих потребительских качеств.

Съёмная зрелость в условиях Черноморского побережья наступает в начале августа, скороплодный, урожайность достигает 1,5-2,0 т/га сухих орехов в скорлупе, отличается стабильностью плодоношения.

Сорт проявляет среднюю устойчивость к заморозкам и засухе, устойчив к следующим вредителям: ореховому долгоносику, почковому клещу, фундучному усачу.

У сорта 'Анастасия' высокое товарное и потребительское качество орехов, самоплодность $(0,92-0,95)$; жизнеспособность пыльцы $(75-80$ \%). 
Является хорошим опылителем, успешно возделывается в штамбовой форме, пригоден для механизированного сбора урожая.

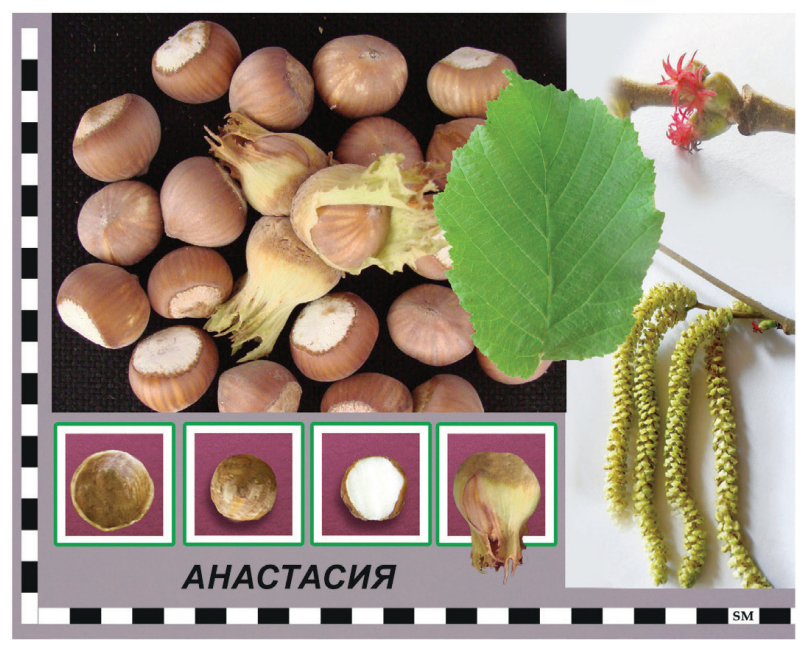

Рис. 1. Сорт 'Анастасия’

\section{Сорт 'ГАЛИНА'}

Сорт раннего срока созревания, селекции ФИЦ СНЦ РАН (ранее ВНИИЦиСК), выделен в 1992 г. среди форм от свободного опыления на Черноморском побережье Краснодарского края (рис. 2).

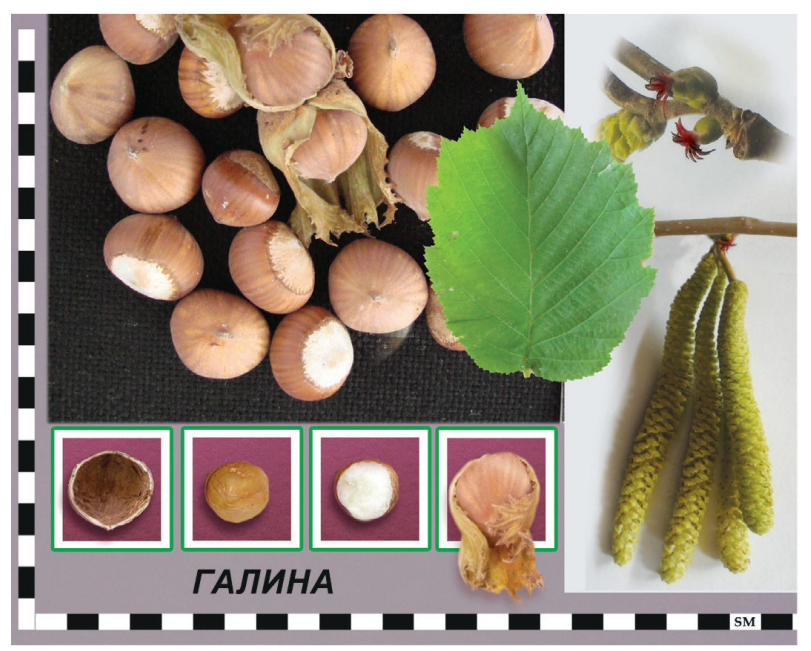

Рис. 2. Сорт 'Галина'

Авторы сорта: В. Г. Махно, А. В. Рындин, Л. В. Черепенина.

Куст средней силы роста, с овальной, средней густоты раскидистой кроной, достигающей 3,5 м высоты и 3,0-3,5 м в диаметре; расположение скелетных ветвей не очень компактное. 
Глава 2. Интродукция и сортоизучение

Орехи: крупного размера (длина 26 мм, ширина 24 мм); форма округлая; вершина слегка заостренная; основание бугристое; собраны в соплодия по 2-8 шт. (в среднем 4-6); обертка (плюска) зелёного цвета, состоит из двух лопастей, немного длиннее ореха, у вершины открытая, рассеченная на несколько удлинённых долей со слабым наплывом у основания, при созревании ореха легко отделяется; скорлупа средняя (толщиной 1,0-1,1 мм), светло-коричневая; ядро массой 1,5-2,0 г, плотное, хорошо заполняет скорлупу и составляет 48-50 \% от общей массы ореха, содержит: жира - 69 \%, белка - 17 \%, витамины В1, В2, В6, Е; в контролируемых условиях плоды хранятся до 3 лет, не теряя своих потребительских качеств.

Съёмная зрелость в условиях Черноморского побережья наступает в III-й декаде июля - начале августа, скороплодный, урожайность достигает 1,9-2,0 т/га сухих орехов в скорлупе, отличается стабильностью плодоношения.

Сорт проявляет среднюю устойчивость к заморозкам и засухе, относительно устойчив к следующим вредителям: ореховому долгоносику, почковому клещу, фундучному усачу.

\section{Сорт 'ВИКТОРИЯ'}

Сорт позднего срока созревания, селекции ФИЦ СНЦ РАН (ранее ВНИИЦиСК), выделен в 1992 г. от свободного опыления сеянцев сорта ‘Академик Яблоков' (рис. 3).

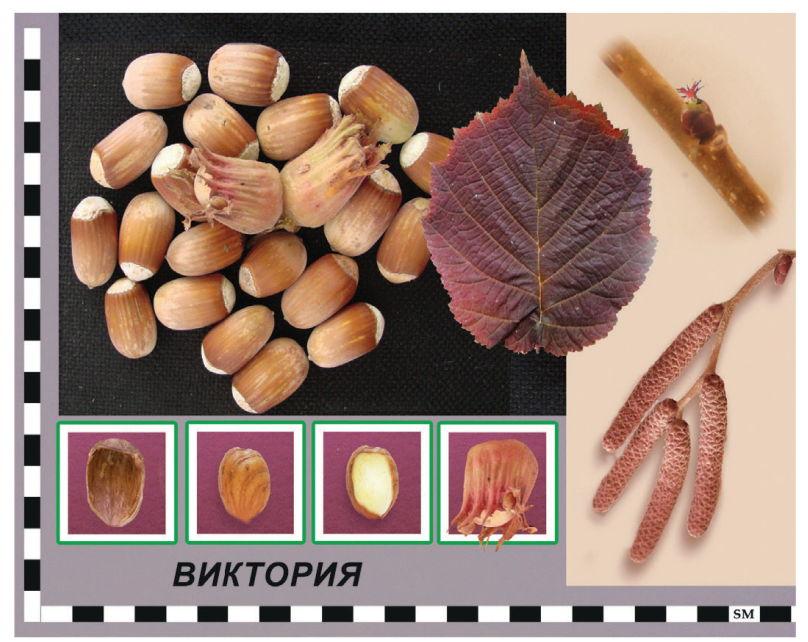

Рис. 3. Сорт 'Виктория'

Авторы сорта: В. Г. Махно, А. В. Рындин, Л. В. Черепенина.

Куст сильнорослый, с овальной, средней густоты кроной, достигающей 5,0 м высоты и 4,0-4,5 м в диаметре; расположение скелетных ветвей компактное. 
Орехи: крупного размера (длина 28 мм, ширина 22 мм); форма удлинённая; вершина тупая; основание вытянутое, бугристое; собраны в соплодия по 2-4 шт. (в среднем 2-3); обертка (плюска) розоватого цвета, состоит из двух лопастей, чуть длиннее ореха, у вершины открытая, со слабым наплывом у основания, при созревании ореха легко отделяется; скорлупа средняя (толщиной 1,1-1,2 мм), слаборебристая, светло-коричневая; ядро массой 1,3-1,5 г, плотное, хорошо заполняет скорлупу и составляет 46-48 \% от общей массы ореха, содержит: жира - 68 \%, белка - $19 \%$, витамины В1, В2, В6, Е; в контролируемых условиях плоды хранятся до 3 лет, не теряя своих потребительских качеств.

Съёмная зрелость в климатических условиях Черноморского побережья наступает в конце августа, начале сентября, скороплодный, урожайность достигает 1,5-2,0 т/га сухих орехов в скорлупе.

Сорт проявляет высокую устойчивость к заморозкам и засухе, устойчив к вредителям: ореховому долгоносику, почковому клещу, фундучному усачу.

У сорта 'Виктория' хорошее товарное и потребительское качество орехов, высокая декоративность (краснолистная) позволяет с успехом применять в ландшафтном и интерьерном дизайне.

Выводы. На базе коллекции ФИЦ СНЦ РАН за последние годы в результате селекционной работы были созданы перспективные сорта фундука: 'Анастасия', 'Галина', 'Виктория', урожайность которых достигает 1,5-2,0 т/га сухих орехов в скорлупе, которые отличаются стабильностью плодоношения, с высокими вкусовыми и полезными качествами, относительно устойчивых к абиотическим и биотическим факторам.

\section{Библиографический список}

1. Махно В.Г., Пчихачев Э.К. Культура фундука - её возможности выращивания в зонах рискованного земледелия. - Майкоп, 1995. - 38 с.

2. Рындин А.В. Генетические ресурсы субтропических, южных плодовых, цветочно-декоративных культур и возможности их использования Государственное научное учреждение всероссийский научно-исследовательский институт цветоводства и субтропических культур Россельхозакадемии // Плодоводство и ягодоводство России. 2009. - T. 22. - Ч. 1. - C. 118-128. - ISSN 2073-4948.

3. Тутберидзе Ц.В. Оптимизация породно-сортовой структуры южного садоводства // Субтропическое и декоративное садоводство. - 2015. - Вып. 53. - С. 65-71. - ISSN 2225-3068. 4. Рындин А.В. Адаптивное садоводство влажных субтропиков России: дис. ...д-ра с.-Х. наук. - Краснодар, 2009. - 380 с.

5. Рындин А.В., Кравцов И.А., Мохно В.С. Состояние и перспективы селекционных исследований по субтропическим и цветочным культурам на юге России // Инновационные подходы в селекции цветочно-декоративных, субтропических и плодовых культур: мат-лы науч.-практ. конф., 21-24 сентября 2005 г. - Сочи: ВНИИЦиСК, 2005. - С. 3-16. 
6. Тутберидзе Ц.В. Орех // Контрольная закупка. - 2017. - С. 88-91.

7. Махно В.Г. Использование рода Corylus в декоративном и промышленном садоводстве // Субтропическое и декоративное садоводство. - 2014. - Вып. 50 - С. 232-235. - ISSN 2225-3068.

8. Махно В.Г.; Дыбов А.И.; Хавелов Е.П. Практические основы возделывания фундука в Российской Федерации: монография. - Белгород: ЛитКараВан, 2015. - 205 с. - ISBN 978-5-902113-87-4.

9. Программа и методика сортоизучения плодовых, ягодных и орехоплодных культур. - Орел: Изд-во Всероссийского научно-исследовательского института селекции плодовых культур, 1999. - 608 с. - ISBN 5-900705-15-3.

10. Починок Х.Н. Методы биохимического анализа растений. - Киев: Наукова думка, 1976. $-334 \mathrm{c}$.

11. Махно В.Г. Формовое разнообразие фундука - источник создания современных сортов юга России // Инновационные подходы в селекции цветочно-декоративных, субтропических и плодовых культур: мат-лы науч.-практ. конф., 21-24 сентября 2005 г. Сочи: ВНИИЦиСК, 2005. - С. 97-104.

12. Махно В.Г., Луговской А.П., Чепурной В.С. Каталог сортов и форм фундука. Краснодар, СКФНЦСВВ, 2014. - 165 с.

13. Abbot W.S. A method for computing the effectiveness of insecticide // 1. Econ. Entomol. - 1975. - Vol. 18. - P. 265-267.

\title{
CHARACTERISTICS \\ OF NEW GENERATION HAZELNUT CULTIVARS \\ IN THE FEDERAL RESEARCH CENTRE \\ THE SUBTROPICAL SCIENTIFIC CENTRE OF THE RUSSIAN ACADEMY OF SCIENCES CROPS COLLECTION
}

\author{
Makhno V. G., Tutberidze Ts. V., Besedina T. D. \\ Federal Research Centre \\ the Subtropical Scientific Centre of the Russian Academy of Sciences, \\ Sochi, Russia,e-mail:supk@vniisubtrop.ru
}

An assortment is the most important element in the technology of growing hazelnuts (Corylus pontica C. Koch). A Cultivar with a complex of economically valuable characteristics is the basis for producing high-quality and competitive fruits (nuts) of this highly valuable crop. The main base for hazelnut breeding is the gene pool, which was formed in the FRC SSC RAS by introducing cultivars and forms from various natural regions of the CIS and Europe, as well as by adding forms and cultivars from their own breeding. As a result of the breeding work carried out highly productive hazelnut cultivars were created and registered in 2019, in the State Register of Protected Breeding Achievements of the Russian Federation, including early flowering cultivars: 'Anastasia', 'Galina' and a late one - 'Victoria'. They are characterized by stable fruiting, high taste and useful qualities, being relatively resistant to abiotic and biotic factors.

Key words: hazelnut, collection, cultivars, bush, shoots, leaves, female and male flowers, nuts (fruits), advantages and disadvantages of the cultivar. 